\title{
IMPLEMENTASI PENDIDIKAN KARAKTER RELIGIUS DITINJAU DARI PENGASUHAN PERNIKAHAN BEDA AGAMA
}

\author{
Aisyah $^{1}$, Isabella Hasiana ${ }^{2}$ \\ ${ }^{1,2}$ Pendidikan Anak Usia Dini Fakultas Keguruan dan Ilmu Pendidikan Universitas PGRI Adi Buana \\ Surabaya \\ Email : aisyah.baswedan@yahoo.com¹,icha1916@yahoo.co.id ${ }^{2}$
}

\begin{abstract}
Abstrak
Manusia adalah makhluk sosial yang tidak akan bisa terlepas untuk berhubungan dengan orang lain. Hubungan yang terjalin tersebut terutama antara pria dan wanita yang sudah dewasa dapat berlanjut sampai ke jenjang pernikahan. Ditengah masyarakat yang memiliki beraneka latar belakang budaya, suku dan agama, maka tidak menutup kemungkinan terjadi pernikahan campur, yaitu pernikahan yang terjadi antar agama. Pernikahan beda agama tentunya tidak lepas dari konflik yang muncul terutama yang berkaitan dengan pola pengasuhan anak dalam mengembangkan nilai karakter yaitu religius. Penelitian ini merupakan jenis penelitian kualititatif dengan subyek penelitian sebanyak lima pasangan keluarga yang melakukan pernikahan beda agama. Hasil dari penelitian ini adalah bahwa faktor keteladanan dan pembiasaan merupakan faktor yang utama dan mendasar dalam pembentukan karakter religius dan hal ini dilakukan oleh salah satu orang tua saja dengan pemikiran agar anak tidak menjadi bingung akan ajaran agama yang dianutnya.
\end{abstract}

Kata kunci : karakter religius, pola pengasuhan, pernikahan beda agama

\section{PENDAHULUAN}

Pada hakekatnya manusia sebagai makhluk sosial tidak akan pernah lepas dari hubungannya dengan orang lain. Dimana hubungan yang terjalin antar individu tersebut ada yang bersifat formal, yaitu yang hanya sekedar basa-basi saja, tidak mendalam dan hubungan yang bersifat mendalam, seperti hubungan sebagai seorang sahabat, mencurahkan isi hati, berkeluh kesah, dan sebagainya. Hal ini juga akan dialami oleh mereka (pria dan wanita) yang telah meningkat dewasa, yang dituntut untuk dapat berhubungan secara mendalam sampai dapat memiliki arti tersendiri di dalam hidupnya, sehingga didapatkan bahwa hubungan tersebut akan berlanjut ke jenjang pernikahan.

Pernikahan adalah upacara pengikatan janji nikah yang dirayakan atau dilaksanakan oleh dua orang dengan maksud meresmikan ikatan pernikahan secara norma agama, norma hukum dan norma sosial. Namun, kenyataannya kita hidup di tengah masyarakat yang heterogenitas sehingga tidak menutup kemungkinan akan terjadi pernikahan campur (Azis, 2015). Pernikahan campur ialah pernikahan yang terjadi antar agama.
Namun, pada dasarnya pernikahan beda agama tentunya tidak lepas dari konflik yang muncul baik secara internal maupun eksternal. Hal ini juga disampaikan oleh Lubis (dalam Azis, 2015) dimana pasangan beda agama memiliki kemungkinan besar untuk tersandung masalah dengan pasangannya. Oleh karena itu diperlukan persiapan psikologis yang cukup matang agar pernikahan yang terjadi berlangsung dengan bahagia terutama dalam mengembangkan pendidikan karakter anak yang berkaitan dengan nilai religius.

Terkait dengan penanaman karakter religius pada anak, muncul pertanyaan bagaimana karakter tersebut ditanamkan oleh orangtua yang menikah beda agama? Seringkali hal tersebut menjadi permasalahan yang muncul. Penelitian yang dilakukan oleh Murtadho (dalam https://murtadhoui.wordpress.com/pendidikanagama-pada-anak-pasangan-orang-tua-bedaagama/) terhadap pola asuh pasangan yang menikah beda agama, ditemukan bahwa ada tiga variasi interaksi keagamaan pasangan beda agama, yaitu pertama, pasangan suami istri kurang kuat dalam beragama (agama 
KTP); kedua, pasangan di mana salah satu pasangan adalah lebih kuat (aktif) dalam beragama; ketiga, pasangan yang sama-sama kuat dalam beragama. Dari hasil penelitian tersebut disimpulkan bahwa pilihan anak dalam beragama pada pasangan beda agama bervariasi, kebanyakan mengikuti pola interaksi agama yang dikembangkan orang tua. Misalnya ada kesepakatan tertentu tentang agama anak, apakah anak mengikuti salah satu agama orang tua atau dibagi atau dibebaskan; maka anak akan cenderung mengikuti pola itu. Berdasarkan latar belakang tersebut, maka penulis mengambil judul "Implementasi Pendidikan Karakter Religius Ditinjau dari Pengasuhan Pernikahan Beda Agama"

Penelitian ini bertujuan untuk mengetahui implementasi pendidikan karakter religius anak pada pernikahan beda agama untuk mengetahui pengaruh implementasi pendidikan karakter religius anak pada pernikahan beda agama

\section{KAJIAN LITERATUR}

\section{a. Implementasi}

Secara sederhana implementasi bisa diartikan sebagai pelaksanaan atau penerapan. Implementasi adalah bermuara pada aktivitas, aksi, tindakan atau adanya mekanisme suatu sistem. Implementasi bukan sekedar aktivitas, tetapi suatu kegiatan yang terencana dan untuk mencapai tujuan kegiatan (Lestari, 2016).

Implementasi berasal dari bahasa Inggris yaitu to implement yang berarti mengimplementasikan. Implementasi merupakan penyediaan sarana untuk melaksanakan sesuatu yang menimbulkan dampak atau akibat terhadap sesuatu.

Dari pengertian diatas, maka dapat disimpulkan bahwa implementasi merupakan suatu aktivitas yang terencana serta adanya sarana yang digunakan untuk melaksanakan sesuatu yang nantinya dapat menimbulkan dampak atau akibat terhadap sesuatu.

\section{b. Pendidikan Karakter}

Dalam kamus besar bahasa Indonesia menjelaskan bahwa karakter adalah sifat atau ciri kejiwaan, akhlak, atau budi pekerti yang membedakan seseorang dari yang lain; tabiat; watak. Dengan demikian, karakter adalah cara berpikir dan berperilaku yang menjadi ciri khas tiap individu untuk hidup dan bekerjasama, baik dalam lingkungan keluarga, masyarakat, bangsa, dan Negara. Individu yang berkarakter baik adalah individu yang bisa membuat keputusan dan siap mempertanggungjawabkan tiap akibat dari keputusan yang ia buat.

\section{c. Pengertian Karakter Religius}

Kata dasar dari religius adalah religi yang berasal dari bahasa asing religion sebagai bentuk dari kata benda yang berarti agama atau kepercayaan akan adanya sesuatu kekuatan kodrati di atas manusia. Sedangkan religius berasal dari kata religious yang berarti sifat religi yang melekat pada diri seseorang. Religius sebagai salah satu nilai karakter dideskripsikan sebagai sikap dan perilaku yang patuh dalam melaksanakan ajaran agama yang dianut, toleran terhadap pelaksanaan ibadah agama lain, dan hidup rukun dengan pemeluk agama lain. Karakter religius ini sangat dibutuhkan oleh anak dalam menghadapi perubahan zaman dan degradasi moral sehingga diharapkan mampu memiliki dan berperilaku dengan ukuran baik dan buruk yang di dasarkan pada ketentuan dan ketetapan agama.

Dalam perkembangan religius ini memiliki perbedaan pada tiap-tiap masa kehidupan individu. Pada masa anak-anak, religius anak masih sangat sederhana sehingga disebut juga dengan the simply religious. Pada saat itu anak memang belum dapat melaksanakan tugas hidupnya secara mandiri, bahkan sampai kepada yang paling sederhanapun. Dalam banyak hal anak harus mempercayakan dirinya kepada pendidiknya. Sehingga pada masa anak, pembentukan karakter religious lebih didasarkan pada factor pembiasaan dan contoh konkrit dari orang tua.

\section{d. Pernikahan Beda Agama}

Pernikahan beda agama adalah pernikahan antara dua individu yang memeluk agama berbeda disebut interfaith marriage, mixed marriage, mixed faith marriage, atau interreligious marriage (Fadlillah dan Khorida. 2013).

Menurut Mandra \& Artadi (dalam Fadlillah dan Khorida. 2013), pernikahan beda agama adalah ikatan lahir batin antara seorang 
pria dan seorang wanita, yang masing-masing berbeda agamanya dan mempertahankan perbedaannya itu sebagai suami isteri dengan tujuan untuk membentuk rumah tangga yang bahagia dan kekal berdasarkan KeTuhanan Yang Maha Esa.

Dalam Negara Indonesia sebagai Negara kesatuan yang berdasarkan Pancasila, maka perkawinan dianggap erat hubungannya dengan agama, sehingga perkawinan yang terjadi bukan saja mengandung unsur luhur namun juga unsur batin. Dalam pasal $1 \mathrm{UU}$ Perkawinan ditetapkan rumusan tentang perkawinan yaitu ikatan lahir batin antara seorang pria dan wanita sebagai suami dan istri dengan tujuan untuk membentuk keluarga (rumah tangga) yang bahagia dan kekal berdasarkan Ketuhanan Yang Maha Esa. Selanjutnya dalam pasal 2 (ayat 1) ditetapkan bahwa Perkawinan adalah sah apabila dilakukan menurut hukum masing-masing agama dan kepercayaannya itu. (http://kuakecamatankarimun.blogspot.co.id/2 013/08/nikah-beda-agama-dalam-pandanganhukum.html).

\section{e. Implementasi Pendidikan Karakter Religius Ditinjau dari Pola Pengasuhan Pernikahan Beda Agama}

Keluarga merupakan tempat yang sangat menentukan terhadap masa depan perkembangan anak. Dari pihak keluarga perkembangan pendidikan sudah dimulai sejak masih dalam kandungan. Anak yang belum lahir sebenarnya sudah bisa menangkap dan merespon apa-apa yang dikerjakan oleh orang tuanya terutama ibu.

Menurut Hurlock (2008), anak-anak akan tumbuh menjadi pribadi yang berkarakter apabila dapat tumbuh pada lingkungan yang berkarakter. Keberhasilan keluarga dalam menanamkan nilai-nilai kebajikan (karakter) pada anak sangat tergantung pada pengasuhan yang diterapkan orang tua pada anaknya.

Keluarga dipandang sebagai pendidik karakter yang utama pada anak, di samping sekolah yang juga dianggap sebagai pusat pengembangan karakter pada anak. Hal ini disebabkan karena pengaruh sosialisasi orang tua pada anak terjadi sejak dini sampai anak dewasa. Sehingga melalui interaksi dengan orang tua, anak dapat merasakan dirinya berharga yang selanjtnya dijadikan dasar untuk menghargai orang lain (Lestari, 2016).

Nilai dasar yang menjadi landasan dalam membangun karakter adalah hormat (respect). Dimana hormat ini sendiri mencakup respek pada diri sendiri, orang lain, semua bentuk kehidupan maupun lingkungan yang mempertahankannya. Dengan memiliki hormat, maka individu memandang dirinya maupun orang lain sebagai sesuatu yang berharga dan memiliki hak yang sederajat terutama berkaitan dengan nilai karakter religius yang terjadi pada anak dengan latar belakang orang tua yang menikah berbeda agama.

Di dalam keluarga yang memiliki multi agama, tentunya implementasi karakter religius ini tidak lah mudah. Orang tua dan anak harus bekerja keras dan berkomunikasi agar tidak terjadi salah paham di antara mereka, yang dampaknya tentu akan dialami oleh anak secara langsung. Misalnya, konflik saat menentukan agama bagi anak, konflik dengan keluarga besar.

Penelitian yang dilakukan oleh Labib (2015) terkait dengan implementasi pendidikan karakter dan pengaruhnya terhadap perilaku akademik siswa, juga menekankan bahwa penanaman nilai karakter yang kuat sejak usia dini, akan membawa pengaruh yang kuat juga dalam akademik anak.

Oleh karena itu, pendidikan karakter merupakan hal yang sangat penting dan utama dalam pembentukan perilaku karakter individu, maka diperlukan peran serta keluarga.

\section{METODE PENELITIAN}

Penelitian ini menggunakan pendekatan kualitatif yang berbentuk studi kasus. Menurut Punch (dalam Sugiono, 2009), studi kasus adalah fenomena khusus yang hadir dalam suatu konteks yang terbatas, meski batas-batas antara fenomena dan konteks tidak sepenuhnya jelas.

Dalam penelitian ini ditentukan sejumlah karakteristik bagi subyek dalam penelitian, antara lain : Merupakan pasangan suami istri yang menikah beda agama dengan kriteria usia pernikahan yang bervariasi antara 5-10 tahun dan telah memiliki anak. 
Metode pengumpulan data yang dilakukan dengan menggunakan wawancara yang mendalam disertai dengan pedoman wawancaranya serta menggunakan observasi untuk mengetahui perilaku subyek penelitian secara umum.

Adapun pedoman wawancara yang diberikan adalah :

1. Berdoa sebelum dan sesudah melakukan aktivitas

2. Merayakan hari-hari besar keagamaan

3. Menyediakan fasilitas yang dapat digunakan untuk beribadah

4. Memberikan kesempatan untuk melaksanakan ibadah

5. Toleransi antar umat beragama

6. Bertanggung jawab atas perbuatan yang dilakukan

7. Disiplin dalam segala hal
Wawancara dilakukan kepada 5 orang subyek penelitian yang melakukan pernikahan dengan pasangan yang berbeda agama. Secara keseluruhan, kelima pasangan ini melakukan pernikahan secara agama dan dicatatkan di catatan sipil meskipun berbeda agama, dan dicatatkan di KUA dengan salah satu pasangan berpindah keyakinan.

Dalam memberikan pendidikan karakter religius bagi anak, keluarga memberikan kewenangan sepenuhnya kepada salah satu orang tua. Hal ini dilakukan dengan tujuan agar anak tidak menjadi bingung dengan agama yang dianutnya. Namun, ada juga keluarga yang tidak terlalu menekankan pentingnya pendidikan karakter religius ini. Orang tua memiliki pemikiran bahwa yang utama anak mengerti dan tahu cara menghargai dan menghormati orang tua.

\section{HASIL DAN PEMBAHASAN}

Tabel 1. Hasil Rangkuman Wawancara

\begin{tabular}{|c|c|c|c|c|c|}
\hline & Subye 1 & Subye 2 & Subye 3 & Subye4 & Subye 5 \\
\hline $\begin{array}{l}\text { Berdoa sebelum dan } \\
\text { sesudah melakukan } \\
\text { aktivitas }\end{array}$ & $\begin{array}{l}\text { Tidak terlalu } \\
\text { menekankan }\end{array}$ & Ya & $\mathrm{Ya}$ & $\mathrm{Ya}$ & Ya \\
\hline $\begin{array}{l}\text { Merayakan hari-hari } \\
\text { besar keagamaan }\end{array}$ & Ya & $\mathrm{Ya}$ & Ya & Ya & Ya \\
\hline $\begin{array}{lr}\text { Menyediakan } & \\
\text { fasilitas } & \text { yang } \\
\text { digunakan } & \text { untuk } \\
\text { beribadah } & \end{array}$ & $\mathrm{Ya}$ & $\mathrm{Ya}$ & $\mathrm{Ya}$ & Ya & Ya \\
\hline $\begin{array}{l}\text { Memberikan } \\
\text { kesempatan untuk } \\
\text { melaksanakan } \\
\text { ibadah }\end{array}$ & $\begin{array}{l}\text { Ya tetapi jarang } \\
\text { dilakukan }\end{array}$ & $\mathrm{Ya}$ & Ya & $\mathrm{Ya}$ & $\mathrm{Ya}$ \\
\hline $\begin{array}{l}\text { Toleransi antar } \\
\text { umat beragama }\end{array}$ & $\mathrm{Ya}$ & Ya & $\mathrm{Ya}$ & Ya & Ya \\
\hline $\begin{array}{l}\text { Bertanggung jawab } \\
\text { atas perbuatan yang } \\
\text { dilakukan }\end{array}$ & $\begin{array}{l}\text { Tidak terlalu } \\
\text { menekankan }\end{array}$ & $\begin{array}{l}\text { Tidak terlalu } \\
\text { menekankan }\end{array}$ & Ya & Ya & Ya \\
\hline $\begin{array}{ll}\text { Disiplin } & \text { dalam } \\
\text { segala hal } & \\
\end{array}$ & $\begin{array}{l}\text { Tidak terlalu } \\
\text { menekankan }\end{array}$ & Ya & $\mathrm{Ya}$ & Ya & Ya \\
\hline
\end{tabular}

Dari tabel diatas, maka dapat dilihat bahwa pola pengasuhan yang dilakukan oleh pasangan yang menikah berbeda agama lebih kepada toleransi antar umat agama. Pihak keluarga juga belum terlalu menekankan pentingnya pendidikan karakter religius ini untuk dikenalkan kepada anak sejak usia dini. 
Tabel 2. Pengasuhan Pendidikan Karakter Religius

\begin{tabular}{|l|l|}
\hline Subyek 1 & Pengasuhan oleh kedua orang tua \\
\hline Subyek 2 & Pengasuhan oleh kedua orang tua \\
\hline Subyek 3 & $\begin{array}{l}\text { Pengasuhan oleh kedua orang tua dengan melihat } \\
\text { jenis kelamin anak. }\end{array}$ \\
\hline Subyek 4 & Pengasuhan oleh Ibu \\
\hline Subyek 5 & Pengasuhan oleh Ibu \\
\hline
\end{tabular}

Dalam hal pengasuhan pendidikan karakter religius, dari tabel diatas dapat dilihat bahwa orang tua juga memiliki peran. Namun tidak menutup kemungkinan juga pengasuhan diserahkan kepada salah satu orang tua. Hal ini untuk menghindari agar tidak terjadi kebingungan dalam diri anak tentang agama yang dianutnya.

Pendidikan karakter terutama tentang nilai religius akan sia-sia jika hal tersebut tidak diimplementasikan dalam kehidupan seharihari. Pendidikan karakter bahwasanya lebih menekankan pada kebiasaan anak untuk melakukan hal-hal yang positif sehingga kebiasaan ini lah yang nantinya akan menjadi suatu karakter yang membekas dan tertanam dalam jiwa sang anak. Dalam mengimplementasikan nilai-nilai pendidikan karakter religis tidaklah mudah, terutama bagi keluarga yang memiliki pasangan berbeda agama. Perlu sikap kehati-hatian agar tidak terjadi konflik internal di dalam keluarga itu sendiri terkait dengan nilai religiusnya. Religius merupakan sikap dan perilaku yang patuh dalam melaksanakan ajaran agama yang dianutnya, toleran terhadap pelaksanaan ibadah agama lain, dan hidup rukun dengan pemeluk agama lain.

Sikap religius dapat ditanamkan kepada anak sejak usia dini dengan memberikan berbagai kegiatan keagamaan untuk anak. Misalnya mengajarkan anak melaksanakan shalat secara bersama-sama, melatih anak berdoa sebelum makan, dan menanamkan sikap saling menghormati terhadap teman sebaya yang memiliki agama berbeda. Selain itu sikap religiusitas kepada anak juga dapat dilakukan dengan melakukan berbagai kunjungan ke tempat-tempat ibadah, supaya masing-masing anak dapat mengenal tempat agamanya masing-masing. Hal-hal ini lah yang ditanamkan kepada anak dari keluarga yang memiliki pasangan berbeda agama.
Keluarga dengan pernikahan beda agama mencoba untuk menanamkan nilai religius ini kepada anak. Salah satunya dengan memberikan pengasuhan pendidikan agama kepada salah satu orang tua agar tidak ada kebingungan dalam diri anak tentang agama yang dianutnya. Namun ada pula keluarga yang juga tidak menekankan tentang nilai religius ini karena menurut mereka lebih baik anak mengerti bagaimana cara menghormati dan menghargai orang yang lebih tua, pendidikan agama nantinya akan bisa mereka pelajari bila sudah dewasa nanti.

Pada dasarnya keluarga dipandang sebagai pendidik karakter yang utama pada anak, disamping sekolah yang juga dianggap sebagai pusat pengembangan karakter pada anak. Hal ini disebabkan karena pengaruh sosialiasi orang tua pada anak terjadi sejak dini sampai anak dewasa. Melalui interaksi dengan orang tua, anak dapat merasakan dirinya sebagai pribadi yang berharga yang selanjutnya dijadikan dasar untuk menghargai orang lain (Lestari, 2016). Nilai dasar yang menjadi landasan dalam membangun karakter adalah hormat (respect). Hal ini juga yang menjadi alasan bahwa ada keluarga yang tidak terlalu menekankan pentingnya pendidikan agama, melainkan pentingnya rasa hormat. Hormat tersebut mencakup respek pada diri sendiri, orang lain, semua bentuk kehidupan maupun lingkungan yang mempertahankannya. Dengan memiliki hormat, maka individu memandang dirinya maupun orang lain sebagai sesuatu yang berharga dan memiliki hak yang sederajat (Lestari, 2016).

Dalam proses selanjutnya, orang tua memiliki sumbangan terhadap karakter anak paling tidak melalui lima cara (Lestari, 2016). Pertama, dengan menyayangi anak, orang tua membantu anak untuk merasakan dirinya berharga. Hal ini juga dilakukan oleh kelima pasangan keluarga tersebut. Bahwa menurut mereka, anak merupakan hal yang tidak 
ternilai dan perlu diajari dengan kasih sayang. Kedua, orang tua menjadikan dirinya sebagai model bagi anak dalam memperlakukan orang lain. Ketiga, hubungan yang hangat antara orang tua dan anak menjadi kekuatan dalam menghadapi pengaruh moral. Keempat, kasih sayang berperan dalam perkembangan penalaran moral. Kelima, kasih sayang mendorong terjadinya komunikasi antara orang tua dan anak yang menjadi jembatan antara kasih sayang dan perkembangan penalaran moral.

Hal-hal yang nyata dilakukan oleh keluarga pasangan yang berbeda agama dalam pendidikan agama adalah memberikan keteladanan atau contoh yang baik bagi anak. Sebab anak khususnya pada berusia dini dikatakan sebagai periode pembentukan kebiasaan melalui proses meniru terhadap apa yang dilihatnya. Selanjutnya juga memberikan pembiasaan kepada anak sejak usia dini juga akan membentuk pribadi dan sikap religius terhadap dirinya. Sebab anak usia dini memiliki daya tangkap yang cepat untuk menerima stimulus ataupun pembiasaan yang diberikan orang tua kepadanya. Pembiasaan yang dilakukan dalam hal mengimplementasikan pendidikan karakter religius pada anak antara lain: membiasakan mengucapkan doa sebelum dan sesudah melakukan aktivitas. Dari lima keluarga yang menjadi subyek penelitian, mereka semuanya membiasakan hal ini kepada anak-anaknya. Namun sekali lagi, kekonsistenan dari orang tua juga perlu, agar karakter religius pada anak semakin melekat.

\section{KESIMPULAN}

Dari hasil penelitian yang telah dilakukan, maka dapat disimpulkan bahwa :

1. Implementasi pendidikan karakter religius anak pada pernikahan beda agama dilakukan melalui faktor keteladanan dan pembiasaan. Hal ini menjadi dasar yang penting karena untuk anak usia dini memiliki daya tangkap yang cepat untuk menerima stimulus ataupun pembiasaan yang diberikan orang tua kepadanya.

2. Pengaruh implementasi pendidikan karakter religius anak pada pernikahan beda agama terbatas pada pengasuhan pendidikan agama ke salah satu orang tua.
Hal ini dikarenakan agar anak tidak merasa bingung dan orang tua pun dapat secara konsisten mengajarkan nilai-nilai religius kepada anak.

\section{REFERENSI}

Aqib, Zainal. 2012. Pendidikan Karakter di Sekolah. Membangun Karakter dan Kepribadian Anak. Yrama Widya. Bandung

Azis. 2015. Pendidikan Keluarga: Konsep dan Strategi. Jakarta

Bungin, Burhan.2004.Penelitian Kualitatif

Fadlillah dan Khorida. 2013. Pendidikan Karakter Anak Usia Dini Konsep dan Aplikasinya Dalam PAUD. Ar-Ruzz Media. Jogjakarta

Hurlock. (2008). Perkembangan Anak. Jilid 2. Jakarta : Erlangga.

Lestari. 2016. Psikologi Keluarga: Penanaman Nilai dan Penanganan Konflik dalam Keluarga. Jakarta

Nur. 2013. Membangun Karakter Anak Melalui Permainan Anak Tradisional. Jurnal Pendidikan Karakter. Tahunn III, Nomor 1, Februari 2013

Santrock. 2008. Life-Span Development. Perkembangan Masa Hidup. Erlangga. Jakarta

Suparlan. 2010. Pendidikan Karakter: Sedemikian Pentingkah dan Apa yang Harus Kita Lakukan. (Online), (http://www.suparlan.com), diakses 4 September 2012.

Sugiono.2009.Metode Penelitian Pendekatan Kuantitatif, Kualitatif dan $R \& D$. Bandung: Alfa Beta .

https://murtadhoui.wordpress.com/pendidikanagama-pada-anak-pasangan-orang-tuabeda-agama/)

http://kuakecamatankarimun.blogspot.co.id/20 13/08/nikah-beda-agama-dalampandangan-hukum.html). 